\title{
Who Wrote Bacon? Assessing the Respective Roles of Francis Bacon and His Secretaries in the Production of His English Works
}

Noel B. Reynolds

Brigham Young University - Provo, nbr@byu.edu

G. Bruce Schaalje

Brigham Young University - Provo, schaalje@byu.edu

John M. Hilton

Brigham Young University - Provo

Follow this and additional works at: https://scholarsarchive.byu.edu/facpub

Part of the Political Science Commons

\section{Original Publication Citation}

"Who Wrote Bacon? Assessing the respective roles of Francis Bacon and his secretaries in the production of his English Works," Literary and Linguistic Computing 2012, doi: 10.1093/llc/ fqs020, http://llc.oxfordjournals.org/content/27/4/409.full.pdf+html

\section{BYU ScholarsArchive Citation}

Reynolds, Noel B.; Schaalje, G. Bruce; and Hilton, John M., "Who Wrote Bacon? Assessing the Respective Roles of Francis Bacon and His Secretaries in the Production of His English Works" (2012). Faculty Publications. 1474.

https://scholarsarchive.byu.edu/facpub/1474

This Peer-Reviewed Article is brought to you for free and open access by BYU ScholarsArchive. It has been accepted for inclusion in Faculty Publications by an authorized administrator of BYU ScholarsArchive. For more information, please contact ellen_amatangelo@byu.edu. 
Correspondence:

Noel B. Reynolds,

Brigham Young University,

Political Science.

E-mail: nbr@byu.edu
Who wrote Bacon? Assessing the respective roles of Francis Bacon and his secretaries in the production of his English works

Noel B. Reynolds

Brigham Young University, Political Science

G. Bruce Schaalje

Brigham Young University, Statistics

John L. Hilton (deceased)

Brigham Young University, Statistics

\section{Abstract}

In an earlier study that identified previously unrecognized writings of the young Thomas Hobbes, questions were raised about the authorship of some of Francis Bacon's published works. This article reports a follow-up study in which two independent statistical analyses of Bacon's English works both conclude that, whereas Bacon's autographic writings show clearly that they are authored by the same person; almost none of his published works can be matched statistically with the autographs. The most likely explanation for this dramatic finding is that Bacon's well-known reliance on secretaries may have been sufficiently extensive that his writing patterns are obscured or replaced by theirs. This finding suggests a far simpler explanation for a wide array of anomalies in Bacon's works than others have offered. The study further identifies some of Bacon's works written during a period when Thomas Hobbes was his secretary, which match Hobbes's writing pattern.

\section{Introduction}

In an earlier wordprinting study, we identified
Thomas Hobbes as the author of three discourses published anonymously in $1620{ }^{1}$ At the same time we reported ambiguous results in limited comparisons between Francis Bacon and the young Thomas Hobbes-who was occasionally loaned to Bacon as a secretary by the Cavendish family. Subsequently, we have conducted an exhaustive study of Bacon's writings to investigate these lingering questions concerning the authorship of some of Bacon's writings.

Francis Bacon (1561-1626) is widely recognized as one of the two or three most prolific and significant writers of the late sixteenth and early seventeenth centuries. His contributions range from the literary to the philosophical, political, legal, historical, and scientific. And even though his reputation suffered considerably in the nineteenth and twentieth centuries, the scholarship of recent decades has 
restored a sense of his key importance in the advancement of modern science in his times (Peltonen, 1996, pp. 1-2; Zittel et al., 2008, pp. $\mathrm{xx}-\mathrm{xxiii})$. Today his writings on science are often thought to be the most significant of their period. He is usually the first ghost writer suggested when the authorship of other materials from that period is questioned. ${ }^{2}$

But Bacon's writings have also puzzled scholars.

10 How could he possibly have produced so much while maintaining such extensive political and legal involvements? And why do his writings contradict one another so frequently in both content and style? Bacon's interpreters have advanced a variety

15 of explanations for these anomalies over the years, but none of these is entirely convincing. Bacon's career as a writer remains mysterious in these respects and begs for more direct and simple explanations.

Over the last three decades, scholars have developed a variety of techniques for performing statistical wordprinting or stylometric analyses to assist in author attribution for disputed texts (see Holmes, 1985; Peng and Hengartner, 2002; Juola, 2006;

25 Koppel et al., 2009; Stamatatos, 2009). Wordprint studies have proven useful in assessing competing theories about the authorship of such diverse texts as The Federalist and the Pauline epistles. The empirical discovery behind wordprinting is that just as 30 individuals have distinct fingerprints, so also their writings reflect a tendency toward consistent patterns in the usage of common noncontextual terms (words and word patterns that are used at similar rates regardless of context). These patterns have been shown to be both idiosyncratic and statistically detectable in the measurement of a single author's uninhibited prose writing.

The troubling result of the 1993 Hobbes wordprinting study was that we could detect no single

40 identifying pattern in the Bacon selections we were using as controls (Hilton et al., 1997; Fortier, 1997). ${ }^{3}$ In fact, some of the later materials, possibly written when Hobbes was his secretary, displayed wordprint characteristics strikingly close to those viously unconsidered possibility that Bacon was using extensive assistance in his writing. We found

\section{Wordprint Analysis Procedures}

The ability of modern computers to manipulate large texts has made it possible in recent years to perform increasingly sophisticated and statistically reliable wordprint analyses. Because there is no consensus on a single best method for identifying and measuring wordprints, we selected two classical methods of statistical authorship analysisHilton's method (Hilton, 1993; Hilton and Jenkins, 1987) ${ }^{4}$ and a method based on principal components analysis (Joliffe, 1986). ${ }^{5}$ Hilton's method, also referred to as paired-block testing, makes few statistical or mathematical assumptions and has been shown to have a low risk of erroneously declaring two texts to be written by different authors. Rules for declaring that two texts have different authors are empirically based on a control study of known English authors, as are estimates of error rates. The main steps in paired-block testing are as follows:

(1) Blocks consisting of about 5,000 words of single-authored prose text are selectedexclusive of quotations and other elements (such as poetry) that might skew the analysis. 
(2) Each block is divided into several sub-blocks, and each sub-block is measured for the sixtyfive noncontextual word-pattern ratios suggested by Morton (1978). ${ }^{6}$ To enable testing of a broad range of materials simultaneously, Morton devised measures that would be influenced minimally by variations in vocabulary or style, or small shifts in genre or context.

(3) Using the distribution-free Mann-Whitney test (Lehman, 1975) at the 5\% level, the sixty-five word-pattern ratios measured for each text block are compared statistically with the corresponding ratios of every other block. For every pair of text blocks, this measurement produces a distance score consisting of the number of the sixty-five ratios that exhibit a statistically significant difference.

(4) To ensure that the distance score is not influenced by any particular division of the texts into sub-blocks, steps two and three are repeated for forty-nine different divisions into sub-blocks. The new sub-block divisions are generated by increasing an initial word offset. The final distance score for a pair of text blocks is the median number (across repeated sub-block divisions) of the sixty-five tests that exhibit a statistically significant difference according to the Mann-Whitney test.

(5) A decision is made as to whether each pair of texts was written by the same author based on information derived from the control-authors study (Hilton and Jenkins, 1987). Using several modern texts of known authorship, Hilton determined that word blocks drawn from the same author have an average distance score of around 3.2. Some pairs have 0 significantly different word-pattern ratios, and very few have $>6$. On the other hand, word blocks drawn from different authors, when compared with each other, have distance scores between 1 and 17, with an average of about 8.1. Hence, while it is possible for two writers to produce texts with small distance scores, a single author is unlikely to produce texts with large distance scores. Using seven as a cutoff, we would make very few false declarations of distinct authorship.

\section{Texts}

This study includes text blocks attributed to five Elizabethan-period prose writers. The focus is on forty-three 5000-word blocks drawn from Francis Bacon's publications and letters, and twenty-one blocks of text from Thomas Hobbes. To supplement the standard control-author study that undergirds wordprint analyses (see Hilton and Jenkins, 1987), we have also included sixteen text blocks from three other contemporaries of Bacon and Hobbes as additional controls. These include six blocks of text by Fulke Greville, five blocks of text by William (the younger) Cornwallis, and five blocks of text by Richard Tuvill.

From the voluminous published writings of Francis Bacon, we selected works of at least 5,000 words that were originally written in English. We excluded 
Bacon's Latin works because the wordprint methods do not always work for translations. ${ }^{7}$ In order to make this a comprehensive study of Bacon's career, the selected text blocks span Bacon's adult life and represent his favorite published genres. Many of these are professional writings, some are philosophical; and even the religious and purely scientific were included. All but one are generally agreed to be authentic Bacon products, and all appear to reflect at least marginally consistent editing (Bacon and Kiernan, 1985). ${ }^{8}$ The following chart (Table 1) gives the title, best date, and source for the forty-three Bacon text blocks.

Some of the works included in this list require comment. The essays were selected because they are some of the best known of Bacon's writings. Of The Colours of Good and Evil was added because it was about the same time. We took two text blocks from Bacon's paper Certain Observations Made Upon a Libel, and one from Mr. Bacon's Discourse in Praise of His Sovereign, because they display different writing styles and belong to Bacon's earliest publications. A short and frequently doubted work titled Notes on the Present State of Christendom was also included in the study to test the usual assumption that it was not written by Bacon. Bacon's Of The Advancement of Learning was especially important for the study because of its relevance to Bacon's political and scientific philosophy. Three more blocks came from the 1612 edition of Bacon's essays. These blocks included only those essays that had not been in the 1597 version. Three texts from The Arguments of Law were se35 lected to represent Bacon's professional work from this time period. The study also included the work, 'Sir Francis Bacon His Apology, in Certain Imputations Concerning the Late Earl of Essex', a product of severe personal turmoil in Bacon's pol-

40 itical life. We only used the portions of the 1625 essays that had not appeared in the earlier editions. New Atlantis, an important philosophical and scientific work, was the source of three more blocks.

Personal letters of Bacon were also included in the study. Using The Letters and the Life of Francis Bacon and William Rawley's Resuscitatio, we extracted four word blocks from letters that survive published with the essays and probably written in Bacon's own handwriting. We removed greetings, closing comments, and sentences featuring Latin words or phrases so that the texts contained only free-flowing, English prose. With these additions, the study was a comprehensive examination of all of Francis Bacon's English works.

As additional controls, the study also included text blocks known to be written by several of Bacon's sixteenth and seventeenth century contemporaries: Thomas Hobbes, Fulke Greville, Daniel Tuvill, and William Cornwallis. These texts were used to confirm that the wordprinting methods work as expected for Elizabethan English writing. The Hobbes texts were also important in order to investigate the possibility that some Bacon texts were largely written by Hobbes.

Of Hobbes's many works, we selected six text blocks from his most influential political work, Leviathan. We took one text block from Hobbes's On the Life and History of Thucydides, an important historical work. Six more blocks were drawn from On the Elements of Law, thus including some of Hobbes's main legal writings. Hobbes's Behemoth provided three additional text blocks. Last, we selected five text blocks from Three Discourses, with two blocks each coming from 'A Discourse upon the Beginning of Tacitus' and 'A Discourse of Rome', and one text block coming from the briefer 'A Discourse of Laws'?

For Greville, Tuvill, and Cornwallis, we selected a total of sixteen text blocks. Tuvill's selections included three political essays and two theological tracts from his Essays Politic and Moral, and Essays Moral and Theological. All six of Greville's text blocks were drawn from The Prose Works of Fulke Greville, Lord Brooke. And last, we selected five text blocks from William Cornwallis's Essayes. With these additions, we proceeded to our wordprint analyses. ${ }^{10}$

\section{Wordprint Results: Noncontroversial Sixteenth-Seventeenth Century Authors}

Hilton's original control-author study used noncon90 troversial English writings from the eighteenth, 
Table 1 The English works of Francis Bacon used in this study

\begin{tabular}{|c|c|c|c|}
\hline Block & Source Title & Date & Reference $^{a}$ \\
\hline Bacon 1 & Autograph letters & Various & $\begin{array}{r}117,118,237,252,256,262 \\
263,292,293,295,304,313\end{array}$ \\
\hline Bacon 2 & Autograph letters & Various & $\begin{array}{l}\text { I: } 315,320,321,323,324, \\
\quad 347,353,357,360 \text {; II: } 28, \\
\quad 30,32,33,36,65,66,165 \\
\\
190,205,370,371\end{array}$ \\
\hline Bacon 3 & Autograph letters & Various & $\begin{array}{l}\text { III: } 14,57,67,217,257,258, \\
\quad 259,277 ; \text { IV: } 105,106,128, \\
\text { 130, 131, 212, 217, 246, } \\
281,311,324,386\end{array}$ \\
\hline Bacon 4 & Autograph letters & Various & $\begin{array}{l}\text { I: } 350,351,356,361 ; \mathrm{II}: 49 \\
\quad \text { 50, 51, 55, 67, 101, 102, } \\
\quad 104,164\end{array}$ \\
\hline Bacon 5 & The Collected Essaies & 1597 & VI: $525-534$ \\
\hline Bacon 6,7 & Of the Colours of Good and Evil & $1595-96$ & VII: 77-92 \\
\hline Bacon 8 & $\begin{array}{l}\text { Certain Observations Made Upon a Libel Published This Present Year, } \\
1592\end{array}$ & 1592 & VIII: $147-161$ \\
\hline Bacon 9 & $\begin{array}{l}\text { Certain Observations Made Upon a Libel Published This Present Year, } \\
1592\end{array}$ & 1592 & VIII: $147-161,182-199$ \\
\hline Bacon 10 & Mr. Bacon's Discourse in the Praise of His Sovereign & 1592 & VIII: 126-143 \\
\hline Bacon 11 & Notes on the Present State of Christendom & 1582 & VIII: $18-30$ \\
\hline Bacon 12 & The Maxims of the Law & 1597 & VII: 327-341 \\
\hline Bacon 13 & Reading on the Statute of Uses & 1600 & VII: $416-429$ \\
\hline Bacon 14,15 & Of the Proficience and Advancement of Learning, The First Book & $1604-05$ & III: $261-286$ \\
\hline Bacon 16,17 & Of the Proficience and Advancement of Learning, The Second Book & $1604-05$ & III: $321-337$ \\
\hline Bacon $18-20$ & The Collected Essaies (additions to 1597 edition only) & 1612 & VI: 543-591 \\
\hline Bacon 21 & 'The Case of Impeachment of Waste' (from The Arguments of Law) & $1613-16$ & VII: $527-544$ \\
\hline Bacon 22-24 & New Atlantis & 1622 & III: $129-166$ \\
\hline Bacon 25 & $\begin{array}{l}\text { 'Sir Francis Bacon, His Apology, in Certain Imputations Concerning the } \\
\text { Late Earl of Essex' }\end{array}$ & 1604 & X: 141-157 \\
\hline \multirow[t]{2}{*}{ Bacon 26} & A Confession of Faith, & Before 1603 & VII: $219-226$ \\
\hline & Christian Paradoxes & Unknown & VII: 292-297 \\
\hline Bacon 27 & Valerius Terminus & 1603 & III: $217-231$ \\
\hline Bacon 28 & Of the True Greatness of Britain & 1608 & VII: 47-60 \\
\hline Bacon 29 & 'The Jurisdiction of the Marches' (from The Arguments of Law) & $1613-16$ & VII: $587-600$ \\
\hline Bacon 30 & 'In the Case De Rege Inconsulto' (from The Arguments of Law) & $1613-16$ & VII: $687-700$ \\
\hline Bacon 31a & Fragment of Beginning of the History of Great Britain & $1609-10$ & VI: 275-279 \\
\hline Bacon $31 b$ & Fragment of History of the Reign of King Henry VIII & 1622 & VI: $269-270$ \\
\hline Bacon 31c & History of the Reign of King Henry VII & $1621-22$ & VI: $237-245$ \\
\hline Bacon $32-34$ & The Collected Essaies (additions to 1612 edition only) & 1625 & Kiernan, 43-177 \\
\hline Bacon 35 & Sylva Sylvarum: or, Natural History & $1622-26$ & II: $339-359$ \\
\hline Bacon 36 & Sylva Sylvarum: or, Natural History & $1622-26$ & II: $339-359,528-547$ \\
\hline Bacon 37 & Considerations Touching a War With Spain: to the Prince & $1624-25$ & XIV: $469-489$ \\
\hline Bacon 38 & History of the Reign of King Henry VII & $1621-22$ & VI: $27-47$ \\
\hline Bacon 39 & History of the Reign of King Henry VII & $1621-22$ & VI: $27-47,200-225$ \\
\hline Bacon 40 & Advertisement Touching an Holy War & 1622 & VII: $18-34$ \\
\hline Bacon 41 & Physiological and Medical Remains & Unknown & $\begin{array}{l}\text { III: } 799-804,808-809,811 \\
\quad 814,820-821,827-829\end{array}$ \\
\hline Bacon 42 & Ordinances in Chancery & Unknown & VII: 759-772 \\
\hline Bacon 43 & The Use of the Law & Unknown & VII: $463-477$ \\
\hline
\end{tabular}

${ }^{a}$ References of the letters are to the Letters and the Life of Francis Bacon, and the other references are to The Works of Francis Bacon, both edited by James Spedding - except where otherwise indicated. The dates listed refer to the approximate date that it is believed the work was written. The dates for the individual hand-written letters can be found in the sources listed. 
nineteenth, and twentieth centuries. To verify that the paired-block method is useful for Elizabethan era English texts, 666 paired comparisons of the thirty-seven noncontroversial text blocks attributed to Hobbes, Greville, Tuvill, and Cornwallis were carried out (Fig. 1). The results were very similar to the original control-author study. The 245 within-author comparisons produced distance scores ranging from 0 to 7 , with a mean of 2.74 and a standard deviation of 1.34. The 421 between-author comparisons produced distance scores ranging from 1 to 12 , with a mean of 6.14 and a standard deviation of 2.10. Because only one of the 245 true within-author comparisons $(<0.5 \%)$ had a distance score of $\geq 7$, we continued Hilton's practice of declaring controversial text pairs with a distance score of $\geq 7$ as being of distinct authorship. The error rate is again expected to be $\sim 0.5 \%$.

The principal components analysis yielded similar results for the noncontroversial texts (Fig. 2). Text blocks from the same author tended to cluster in the principal components plots. The Hobbes cluster is somewhat less compact than the others in part because the number of Hobbes texts was much higher than for the other authors.

\section{Bacon Texts}

Paired-block wordprint analysis of the forty-three Bacon text blocks produced surprising results. Distance scores for pairs of Bacon texts ranged 30 from 0 to the very high value of 16 , with a mean of 6.56 and a standard deviation of 3.18. The distribution of distance scores for pairs of Bacon texts was similar to that for Bacon texts paired with known non-Bacon texts (Fig. 3), and was also similar to that for differently authored non-Bacon Elizabethan texts (Fig. 1). In principal components plots (Fig. 4), the Bacon texts as a whole did not form anything like a compact cluster, and there was a great deal of overlap with the cluster of Hobbes texts. Hence, the evidence from both statistical analyses clearly indicates that Bacon (at least alone) did not author all of the texts historically attributed to him.

Using both paired-block analysis and principal components analysis, we examined the Bacon text

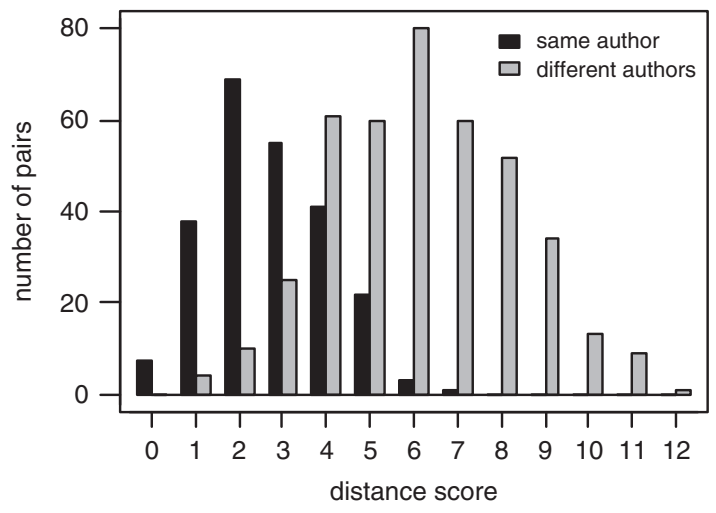

Fig. 1 Distance score distributions for paired-block comparisons of thirty-seven noncontroversial texts of four Elizabethan authors (Note that distributions for the two types of comparisons have different heights simply because the numbers of pairs of texts differ for the two types).

with similar wordprints (small distance scores and obvious clustering on the principal components plot) could be identified. Such a subset could be argued to have a clearly defined 'pure Bacon' wordprint. It turned out that the four blocks of Bacon's personal letters (autographs) comprised such a subset. The six pairs of these texts had a mean-distance score of 2.33 , with a standard deviation of 0.56 . They also formed a fairly compact cluster in the principal components plot (Fig. 4). These observations suggest that Bacon did, in fact, have a consistently measurable wordprint seemingly in common with other writers.

Having learned that the autographs do successfully define Bacon's wordprint, we compared all of the other Bacon texts to the autographs (Fig. 5). The 156 pairs of texts, consisting of one of the autograph texts and one of the other Bacon texts, had a mean distance score of 8.30 , with a standard deviation of 3.14. Over half (57\%) of the text pairs had distance scores of $\geq 7$, strongly suggesting the extensive involvement of other hands in the composition of most of Bacon's published texts.

Of the entire group of Bacon texts, only one had consistently small distance scores when paired with each of the Bacon autographs. The Apology (Sir Francis Bacon His Apology... Concerning the 


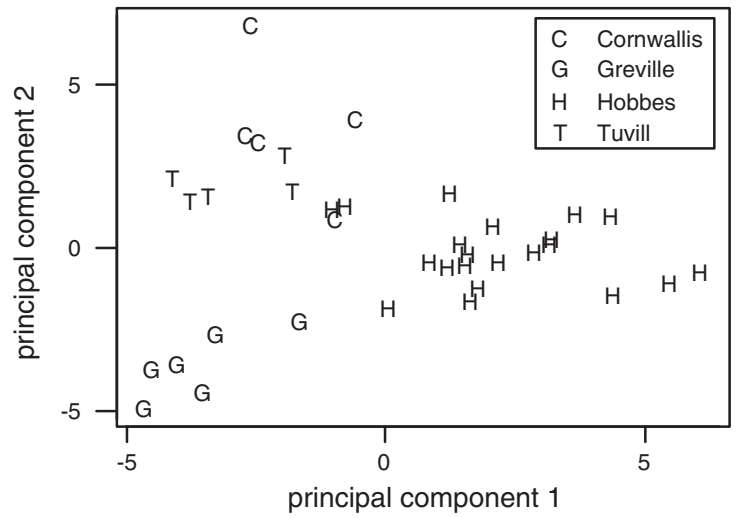

Fig. 2 Principal components plot for thirty-seven noncontroversial texts of four Elizabethan authors.

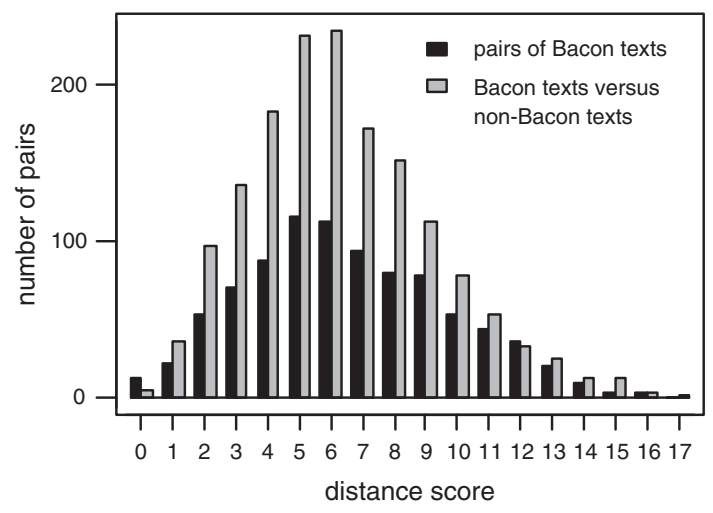

Fig. 3 Distance-score distributions for paired-block comparisons of Bacon texts paired with other Bacon texts, and Bacon texts paired with Cornwallis, Greville, Hobbes, and Tuvill texts (Note that distributions for the two types of comparisons have different heights simply because the numbers of pairs of texts differ for the two types).

Late Earl of Essex), written by Bacon to save his career in a complicated political crisis, revealed a wordprint close to that of his letters. It had a mean-distance score of 2.25 from the autographs, and none of the distance scores were as large as 7. It was located well within the cluster of the autographs in the principal components plot (Fig. 4). All the other published materials appeared to be either ambiguous or clearly not written by Bacon alone. We

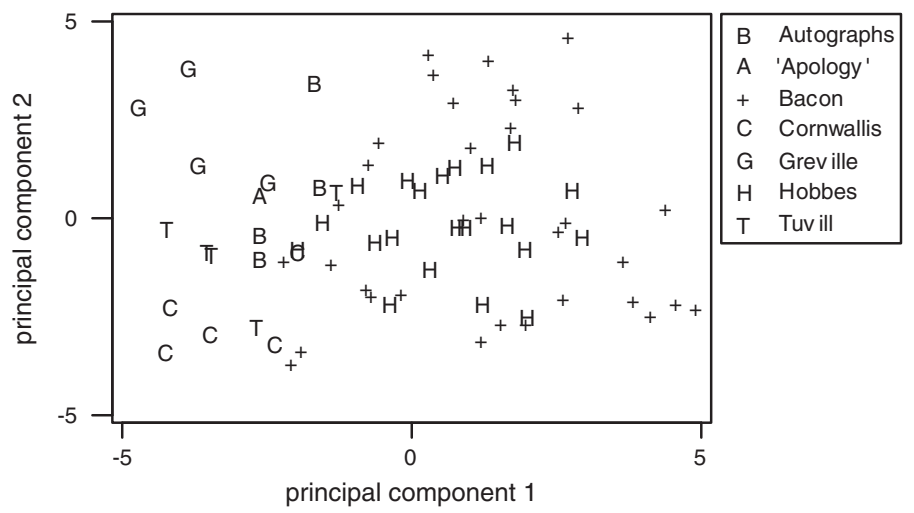

Fig. 4 Principal components plot for texts attributed to Francis Bacon, as well as noncontroversial texts of four other Elizabethan authors. Note that the Bacon autographs and the 'Apology' are denoted with different symbols than the other Bacon texts.

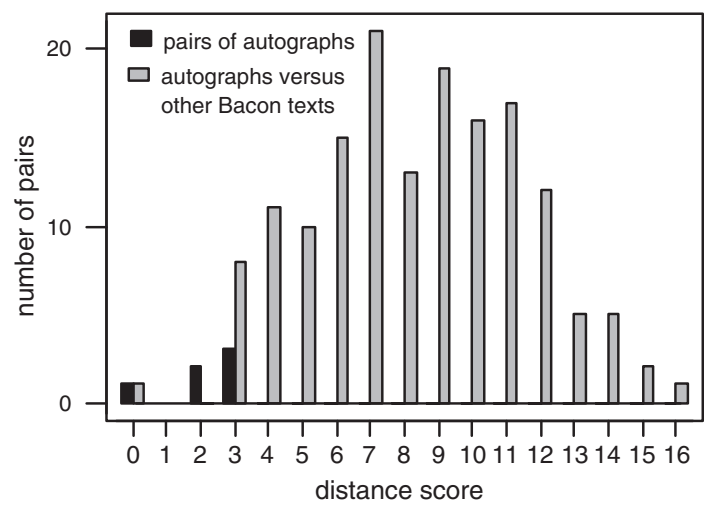

Fig. 5 Distance score distribution for paired-block comparisons of the Bacon autographs with each other and with the other Bacon texts. (Note that distributions for the two types of comparisons have different heights simply because the numbers of pairs of texts differ for the two types.)

the 'pure Bacon' wordprint to include the Apology in addition to the four autograph text blocks.

Distance scores were computed for the remaining thirty-eight Bacon texts paired with the Bacon autographs and the Apology (Table 2). The text with the 15 smallest mean distance from the autographs and the Apology came from the first third of the New 
Atlantis text. This text is not as precisely similar to the Bacon handwritten texts as is the Apology, yet it is well inside the extremes of the within-author distance score distribution for Elizabethan authors

(Fig. 1). It is thus possible that at least part of the first New Atlantis block is Bacon's writing. It is striking, however, that the second and third parts of the full New Atlantis text both have very different wordprints than the Bacon autographs and the Apology, and do not appear to be Bacon's writing.

Twenty-five of the remaining thirty-seven Bacon texts had mean distance scores from the autographs and the Apology exceeding 7, and therefore are almost certainly not Bacon's own writing. The twelve texts with smaller mean distances had scores ranging from 4.60 to 6.80 . These distances are large enough to raise questions about single authorship by Bacon, but no firm conclusions can be drawn. Hence, dramatically unlike all four of the Elizabethan writers that we studied in the control-author study, most of Bacon's text blocks were apparently not written by Bacon-at least not using the personal noncontextual word patterns that Bacon consistently used in his handwritten letters. Apparently he either co-authored most of his papers or completely used other writers' words or works.

\section{Comparison of Bacon Texts to Thomas Hobbes's Wordprint}

When dealing with co-authored texts, the familiar statistical properties of paired-block wordprint comparisons are compromised because the control author studies used only singly authored texts. It is impossible to say in general how distributions of distance scores are affected as larger portions of the text blocks are co-authored by writers with more or less dissimilar noncontextual word patterns. Of course, if the text was essentially written by one co-author with only minimal rewording from another's editing, then the noncontextual word patterns should almost match those of the principal author. ${ }^{11}$ Hence, we used paired-block wordprint methods to investigate the possibility, suggested by the principal components plot (Fig. 4), that Thomas Hobbes was the principal author of some of the texts historically attributed to Bacon.

We note at the outset that the nature of paired-block wordprint analysis, compounded by the fact that many of the Bacon texts may have been co-authored, makes the evidence that paired-block wordprint analyses can provide far from conclusive. Whereas we can show which of Bacon's works may have been authored by any particular secretary (such as Hobbes), scholars will need to rely on other kinds of evidence before they conclusively attribute any particular work to that secretary. Historical evidence, content analysis, and stylistic analysis all have roles to play.

Nevertheless, to explore the possibility that some of Bacon's published work might have been written primarily by Hobbes, we paired all thirty-nine of Bacon's nonautograph text blocks with the twenty-one Hobbes texts. Seven or eight of these texts have distance scores consistent with sole authorship by Hobbes (Table 3), and seven or eight more are similar enough to suggest significant contributions by Hobbes to the writing. However, we note that the Bacon texts in rows 1, 2, 4, 5, 6, 12, and 14 of Table 3 were probably written before Hobbes was available to assist Bacon in the writing of these texts. It is also interesting that, whereas the first two blocks of text from New Atlantis have distance scores consistent with sole or partial authorship by Hobbes, the third New Atlantis block had a mean distance score of 8.43 from the Hobbes texts and is therefore almost certainly not authored by Hobbes.

\section{Interpretations of Bacon's Style}

Bacon scholars have offered a variety of explanations for the ambiguities in Bacon's writings, and particularly the New Atlantis, with its obvious stylistic shift in the final section. Howard White explains them by dividing Bacon's thought into 'provisional' thinking and 'definitive' thinking, or that of a provisional political science to maintain an atmosphere in which to make and implement a right interpretation of nature-the ship that would take man to the New Atlantis. Until arrival at 
Table 2 Mean-distance scores for thirty-eight Bacon texts when paired with the four autographs and Apology, ordered by mean distance.

\begin{tabular}{|c|c|c|}
\hline Bacon text & $\begin{array}{l}\text { Mean distance } \\
\text { score }\end{array}$ & $\begin{array}{l}\text { Number of } \\
\text { distance scores } \geq 7\end{array}$ \\
\hline New Atlantis, part A & 3.60 & 0 \\
\hline Of the Colours of Good and Evil & 4.60 & 0 \\
\hline Certain Observations Made Upon a Libel, part A & 5.50 & 2 \\
\hline Of the Colours of Good and Evil, The Collected Essaies (1597) & 5.40 & 1 \\
\hline The Collected Essaies, published in 1612, part B & 5.40 & 0 \\
\hline Valerius Terminus & 5.60 & 1 \\
\hline History of Great Britain, History of Henry VIII & 5.60 & 2 \\
\hline Considerations Touching a Holy War With Spain & 6.00 & 3 \\
\hline The Collected Essaies, published in 1625, part A & 6.40 & 2 \\
\hline The Collected Essaies, published in 1597 & 6.40 & 2 \\
\hline Mr. Bacon's Discourse In the Praise of His Sovereign & 6.40 & 2 \\
\hline The Collected Essaies, published in 1612, part A & 6.40 & 3 \\
\hline Of The Advancement of Learning, The First Book, part B & 6.80 & 3 \\
\hline New Atlantis, part B & 7.20 & 3 \\
\hline Of The Advancement of Learning, The First Book, part A & 7.20 & 2 \\
\hline Advertisement Touching an Holy War & 7.60 & 3 \\
\hline Of The Advancement of Learning, the Second Book, part A & 7.80 & 4 \\
\hline Certain Observations Made Upon a Libel, part B & 7.80 & 3 \\
\hline Of The Advancement of Learning, the Second Book, part B & 8.00 & 4 \\
\hline The Use of the Law & 8.60 & 5 \\
\hline The History of the Reign of King Henry VII, part A & 8.60 & 4 \\
\hline 'Case De Non Procedendo Rege Inconsulto' from Arg. of Law & 8.80 & 5 \\
\hline Sylva Sylvarum, or Natural History, part B & 8.80 & 5 \\
\hline A Confession of Faith, Christian Paradoxes & 9.00 & 5 \\
\hline New Atlantis, part C & 9.00 & 3 \\
\hline The Maxims of the Law & 9.20 & 5 \\
\hline Of the True Greatness of Britain & 9.20 & 5 \\
\hline History of the Reign of King Henry VII, part B & 9.40 & 4 \\
\hline 'The Case of Impeachment' from The Arguments of Law & 10.00 & 5 \\
\hline The Collected Essaies, published in 1612, part C & 10.40 & 4 \\
\hline 'Jurisdiction of the Marches' from Arguments of Law & 10.60 & 5 \\
\hline The Collected Essaies, published in 1625, part B & 10.80 & 5 \\
\hline Physiological and Medical Remains & 11.00 & 5 \\
\hline The Collected Essaies, published in 1625 , part C & 11.40 & 5 \\
\hline Reading on the Statute of Uses & 11.80 & 5 \\
\hline Sylva Sylvarum, or Natural History, part A & 12.00 & 5 \\
\hline Ordinances in Chancery & 13.20 & 5 \\
\hline Notes on the Present State of Christendom & 14.00 & 5 \\
\hline
\end{tabular}

utopia, tension between the provisional and the definitive could not be avoided, and so, White explains, Bacon created inconsistencies either intentionally or unconsciously as a matter of course. J. G. mind, but into numerous 'compartments' rather than only two, which caused the inconsistencies in his political and intellectual activities, as well as subsequent distrust by others. Mary Hesse offers a similar account showing that Bacon was pragmatic, settling for the best possible means and ends at a given time.

Others see less of a problem with contradictions in content. Jonathan Marwil accounts for inconsistencies by defining Bacon's work as a rhetorical 15 whole, resolving contradictions by simply interpreting his prose into coherence. Peter Urbach agrees with Marwil to some extent; he also sees Bacon's 
Table 3 The fifteen Bacon texts with the smallest mean-distance scores from Thomas Hobbes.

\begin{tabular}{llll}
\hline Bacon text & $\begin{array}{l}\text { Written while Hobbes could } \\
\text { reasonably have assisted }\end{array}$ & $\begin{array}{l}\text { Mean-distance score } \\
\text { from Hobbes texts }\end{array}$ & $\begin{array}{l}\text { Number of } \\
\text { distance scores } \geq 7\end{array}$ \\
\hline Certain Observations Made Upon a Libel, part A & No & 2.71 & 0 \\
Of The Colours of Good and Evil & No & 2.76 & 0 \\
The History of the Reign of King Henry VII, part A & Yes & 2.86 & 0 \\
Certain Observations Made Upon a Libel, part B & No & 3.24 & 1 \\
Valerius Terminus & No & 3.28 & 0 \\
Mr. Bacon's Discourse In Praise of His Sovereign & No & 3.33 & 1 \\
New Atlantis, part A & Yes & 3.43 & 0 \\
History of Great Britain, History of Henry VIII & Yes & 3.57 & 0 \\
Use of the Law & Yes & 3.86 & 0 \\
New Atlantis, part B & Yes & 3.90 & 1 \\
Sylva Sylvarum, or Natural History, part B & Yes & 3.95 & 1 \\
Maxims of the Law & No & 4.00 & 1 \\
Advertisement Touching a Holy War & Yes & 4.10 & 0 \\
Of the True Greatness of Britain & No & 4.19 & 1 \\
The History of the Reign of King Henry VII, part B & Yes & 4.38 & 1 \\
\hline
\end{tabular}

rhetoric as important, calling New Atlantis 'a fable which Bacon himself composed'. John Leary also argues that Bacon's political and philosophical works are a kind of comprehensive whole. Mary Hesse sees Bacon's inconsistencies as a conflict between politics and philosophy but reduces his interest in politics almost entirely to a means of funding himself as 'the prophet of a new science'. William Smedley had argued a stronger version of this view, saying that Bacon preferred an obscure philosophical life without credit even for his writings. Smedley and others have argued that Bacon's reliance on a corps of secretaries lends support to their theory that Bacon was responsible for Shakespeare's writings as well (Smedley, 1912; Crowther, 1960; Hesse, 1964; White, 1968; Marwil, 1976; Urbach, 1987; Leary, 1994).

Other scholars recognize the inconsistencies in more stylistic terms. Michael Kiernan notes an inconsistency in Bacon's use of quotations. Some of his works use many; others use none. Kate Aughterson sees the same kind of inconsistency in Bacon's use of imagery. Robert Adolph offers an account of Bacon's contradictions by attributing them to a utilitarian style of writing, which might be extended to a 'utilitarian passion'. Somewhat like White and Hesse, Adolph argues that Bacon's diversity of styles defies influence-hunters because he always wrote in pursuit of a particular end at a particular time so that his form followed function. It is true that Bacon even mentioned the utility of using different styles (Adolph, 1968, pp. 38, 46-49, 74-76; Kiernan, 1985; Aughterson, 1992;).

These scholars offer plausible answers to the question of puzzling inconsistencies in Bacon's thinking and writing style. On the question of the volume of work he produced, however, they say little.

\section{Bacon's Secretaries}

Bacon's publications not only gained him notoriety as a thinker and writer, but earned him significant public exposure in the political world and particularly at court. Born into a family in royal service, he inherited a thoroughly political life. But this did not prevent him from claiming that all knowledge was also his province. From this combination of politics and philosophy came his commitment to a British empire built on scientific knowledge-the pursuit of a New Atlantis. But Bacon's tumultuous political career made it difficult for him to focus on his intellectual interests. Consequently, many of his biographers have regarded him as a political man first and foremost and a theorist second, recognizing that he never constructed a systematic political theory. 
The results of our wordprint analysis lend substantial support to other scholarship which suggests that Bacon relied on others to produce his philosophical works by following his general instructions, whereas his time and energies were consumed by political life. Further support for this explanation comes from the number of secretaries that Bacon employed throughout his life. The extent of Bacon's household, especially at the height of his 10 political power, suggests he had ready access to such assistance. In 1618, a list only half-extant reveals that his retinue included seventy-two staff members. John Aubrey, a contemporary and friend of Thomas Hobbes who wrote short biographies on many of his contemporaries, recorded that Bacon 'was wont to contemplate in his delicious walkes at Gorhambery, and dictate to Mr. Thomas Bushell, or some other of his Gentlemen, that attended him with inke and paper ready to sett down presently his Thoughts'. According to Aubrey (who was probably relying on Hobbes as his source) Thomas Hobbes was Bacon's favorite secretary and better at 'taking his thoughts, then [than] any of the other(s)'. Besides Bushell and Hobbes, William Rawley, Thomas Meautys, John Young, and Peter Boener, among others, served as secretaries (Aubrey and Dick, 1957; Epstein, 1957, pp. 3-4; Jardine and Stewart, 1999).

Bacon also consulted a wide range of contemporaries regarding his works and thoughts including Toby Mathew, Thomas Bodley, Robert Cotton, John Selden, Henry Savile, John Danvers, Ben Jonson, Edward Sherburn, Fulke Greville, and Bishop Lancelot Andrews; additionally, Bacon's brother Anthony and friend Nicholas Faunt may have participated in some way in the development of his thought and writings. Anthony sent sonnets, official reports about European affairs, and his own speculations on social life back to England from

40 France throughout the late 1500s; and he had connections with the Earls of Essex and Southampton and with Robert Sidney, who also wrote poetry. Anthony or Faunt may have written Bacon's Notes on the State of Christendom. Bacon dedicated his first played some part in producing them (Du Maurier, 1975, pp. 53-54, 180-181; Spedding et al., 1857-74).

Not only did Bacon employ assistance in publishing, he offered it also. Bacon's versatility as an amanuensis has been clearly recognized and documented by his biographers. Not only did he help write uncounted letters and other documents for the Earl of Essex's signature, he also wrote forged letters from Essex to promote his own career, and he wrote the declaration used by the queen to justify her execution of Essex for treason (Jardine and Stewart, 1999). He also assisted James I by writing tracts on various subjects in his name. Political writing was often a collective effort, with Bacon on both sides of the byline and seldom entirely represented by it - a practice that is still common among public officials.

Bacon got his own start in life working as a ghostwriter in the 1580s and 1590s in the employment of the Earl of Essex with a team of writers who produced correspondence and other writings for the earl. While no one has been able to demonstrate that Bacon wrote any particular item for Essex, Bacon's most recent biographers note that 'the complex procedures of commissioning, drafting, revising, editing and publishing in this sort of situation put the "authorship" of any given piece of writing beyond recall'. But it was perfectly clear that Bacon went away from this experience with 'a true understanding of how the intricacies of this system might be exploited to his own advantage'. Given the length of Bacon's service to Essex and its formative role at the beginning of his career, it may seem strange that his own memoirs fail to mention 'the country house, with its coterie of writers, thinkers and experimenters, as a significant part of his own development and the evolution of his Great Instauration'. His biographers speculate that 'the years of intimacy with the Earl of Essex were in the end too painful for him to wish to recall' (Jardine and Stewart, 1999, pp. 132, 139).

Bacon's own sensitivity to the differences between the writing styles of different authors was recorded in an account of the queen's efforts to develop a case for treason out of John Hayward's book, Henry IV. When she suggested torture to get Hayward to confess the true author, Bacon suggested a less objectionable method. 'Let him have pen, ink, and paper, and help of books, and be 
enjoined to continue the story where it breaketh off; I will undertake, by collecting [i.e. collating and comparing] the styles to judge whether he were the author or no' (Jardine and Stewart, 1999,
5 p. 211).

Rawley, certainly an admirer of his friend and employer, wrote that Bacon was not one who in conversation would appropriate the speech wholly to himself, or delight to outdo others, but leave the

liberty to the co-assessors to take their turns. 'Whereupon he would draw a man on and allure him to speak upon such a subject, as wherein he was peculiarly skillful, and would delight to speak' (Du Maurier, 1975, p. 41). The evidence of the wordprints suggests that Bacon may have played a similar role in the production of his writings as he did with conversation.

Bacon was not, however, entirely removed from the publication of his works. Although he may have assigned out much of the initial drafting, he may have been more active in the editing and revision process. Michael Kiernan analyzed each edition of Bacon's essays and found changes in spelling, syntax, diction, and ideas themselves, and sometimes the replacement of words or entire phrases in Bacon's own handwriting. Bacon sometimes interrupted the printing process so he could make further changes. The concern for detail here may have been motivated by his distance from the original production of the works.

Political life in early seventeenth-century Britain was tumultuous, particularly for a man who was defending the prerogatives of the Jacobean court against increasing demands for parliamentary supremacy. Bacon's interest in a stable polity for the sake of science often put him at odds with both the crown and commons, although his higher allegiance was to the crown. He was born to the Lord Keeper of the Seal under Elizabeth, groomed for a political life, and motivated by family tradition to secure a successful career and live the accordant lifestyle. But his father failed to prepare financially for him, which made court politics seem necessary for his advancement. Under Queen Elizabeth he had little success. Except for his uncle Lord Burghley's assistance in securing him a seat in Parliament in 1581 and Elizabeth's pulling him 'over the bar' in 1582, he failed to advance and remained relatively obscure in Parliament, notwithstanding intense efforts to gain a significant government post. A series of gaffes and blunders during the 1580s and 1590s postponed his success until he gained positions of prominence in the Parliaments of 1597 and 1601. He fared much better under James I, having learned from his past failures in court politics. After obtaining a knighthood in 1603, he ascended to the office of Learned Council in 1604, Solicitor General in 1607, Attorney General in 1613, Privy Councillor in 1616, Lord Keeper in 1617, Lord Chancellor in 1618, and was named Viscount of St Albans in 1621, just before his prosecution, conviction, and expulsion for accepting bribes.

Bacon's time during these 40 years was consumed with political activity, court politics, and intrigue. His attention was focused on gaining the 'great place' that would make him a servant of the state, and give him the fame, business, power, literary renown, and opulent financial independence he sought. Joel Epstein describes Bacon's life as one on a political 'treadmill assuring him total status as a "political man", which would, in Bacon's words, give him the 'power to do good [which] is the true and lawful end of aspiring'. But after fighting his way to the top, he 'lost his zeal for carrying out reform' (Epstein, 1977, pp. 180-181). Throughout the 1580s and 1590s he was occupied with his struggle to gain government office, and thereafter the struggle continued as he moved toward the pinnacle of his career. These continual demands on his time and energies would necessarily require substantial assistance in producing literary works.

Thus, many scholars agree that Bacon's political writings were provisional and that his intellectual works were directed at least in part toward political ends. He wrote flattering letters to Elizabeth to gain favor and office. He wrote for Essex and James, who were interested in intellectual innovation, and he sought both their favors in hopes of sparking an intellectual revolution at court so power could be used for the advancement of learning. Rawley wrote that Bacon intended his writings to increase his fame at home to match that which he enjoyed abroad. With expedience as the impetus, he 
published substantial works and advanced far beyond his once obscure position in Parliament. After his conviction and fall from power, during his most intellectually productive years, he maintained an interest in the affairs of state and may have written even then to revive his career. Epstein argues that Bacon wrote the Advancement of Learning and many other works to gain favor with James and the History of Henry VII to regain it.

10 Kiernan, Marwil, and Peltonen agree that many, if not most of his works, possibly even his reports on his scientific experiments, were produced for the purpose of gaining political place (Works, 1:53; Epstein, 1977, pp. 78, 174, note 52; Cornwallis and Allen, 1946, p. xxvi; Peltonen, 1992).

This account of political ambition is consistent with Adolph's description of Bacon's utilitarian method of writing. Utility was of utmost importance to Bacon, at first in the pursuit of a truly great Britain as a scientific utopia, and thereafter in the pursuit of a great place, the power necessary to serve the state and gain fame and financial independence. In each case, the pursuit of power consumed virtually all of Bacon's time and attention. The use of secretaries may have made his political career and literary renown possible. Even though his income eventually rose to high levels, his lavish spending undermined his hopes for financial independence, and he died deeply in debt.

\section{Hobbes and Bacon}

We have noted Hobbes's position as a particularly favored secretary during a vaguely defined period near the end of Bacon's life. Hobbes's employer, William Cavendish (the younger), possibly became acquainted with Bacon at Parliament in 1614. Cavendish wrote ten essays in Baconian style in 1615 , corresponded with him by 1616, and received Bacon's assistance in his (or Hobbes's) translation of Bacon's Essayes into Italian before its publication in 1618. Clearly, Hobbes, who served as Cavendish's tutor and secretary, would have become acquainted with Bacon during the same period. Cavendish's correspondence with Fulgentio Micanzio, secretary to Paolo Sarpi (Venice's state theologian), which numbered some seventy-five letters between 1615 and 1628, also establishes his acquaintance with Bacon. Micanzio frequently lauded Bacon's essays, worked to have Bacon translated in Italian, began his own correspondence with Bacon, and often asked Cavendish to give his regards to Bacon. Financial records also indicate that Hobbes visited Bacon on behalf of his employer in May 1619 and May 1620 (Malcolm, 1984, pp. 47-54; Malcolm, 1996, p. 18; Martinich, 1999, pp. 28-29, $37-40,54,65)$.

As previously mentioned, Aubrey claimed that Hobbes served as Bacon's secretary, making two explicit references to their relationship. In his sketch of Bacon, besides asserting that Hobbes was his source of information regarding the cause of Bacon's death, he noted, 'Mr Thomas Hobbes was beloved by his Lordship, who was wont to have him walke with him in his delicate groves where he did meditate: and when a notion darted into his mind, Mr. Hobbs was presently to write it downe, and his Lordship was wont to say that he did it better than any one els about him; for that many times, when he read their notes, he scarce understood what they writt, because they understood it not clearly themselves'. Likewise, in his sketch of Hobbes, Aubrey noted Hobbes's dictation skills, as well as stating that 'The Lord Chancellour Bacon loved to converse with him. He assisted his Lordship in translating severall of his Essayes into Latin, one, I well remember, is that $O f$ the Greatnes of Cities'. ${ }^{12}$

A final indication of Hobbes's service to Bacon comes from a letter from Froncois de Verdus, a French friend, to Hobbes in 1664. De Verdus wrote of his plan to dedicate his translation of Bacon's De sapientia veterum, which was never published, to Hobbes; 'for that purpose', he queried, 'I should like to know precisely about something which I think I was told a long time ago, namely, that you were a secretary to this Chancellor Bacon in his studies' (Hobbes and Malcolm, 1994, pp. 625-29).

Because our statistical analysis and the wordprinting model, it presumes, are much better at showing us what someone did not write than what they did, it cannot provide conclusive proof that any particular secretary wrote any particular Bacon text. 
Only when historical and textual evidence confirms the connection of a particular secretary with a text are stronger conclusions justified. Our comparison of Thomas Hobbes's wordprint with the Bacon corpus provides a good example of these issues. From our baseline studies, it would seem quite possible that Hobbes authored some of the published Bacon works. But the early dates of publication for some text blocks so identified show that they were written before Hobbes is known to have been available to Bacon for that kind of assistance, and thus at least for these cases the pattern measurements give a false positive. The most intriguing possible major involvement by Hobbes is in the first and middle sections of New Atlantis, which, if recent scholarly opinion is correct, were composed in 1624 , the most likely period for Hobbes to have been working with Bacon (Peltonen, 1996). The first two of the three word blocks drawn from New Atlantis, whereas not 20 matching perfectly, fit quite comfortably with Hobbes's wordprint.

While a follow-up study focusing on the secretaries might possibly identify more clearly the authors for some of the texts, it needs to be recognized

25 that in its present stage of development, wordprinting is still a blunt instrument when working with non-single-authored text blocks. Wordprinting depends on collateral textual and historical studies for many of its conclusions where text blocks are not 30 single-authored free-flow works. While it might be possible to tease out further direct connections between specific secretaries and particular texts, the main conclusion we can confidently defend at this point is negative: most of Bacon's works were not likely written solely by Bacon. The actual extent of his involvement in producing each of the works attributed to him remains a question for further interdisciplinary study.

\section{Conclusions}

40 Wordprinting analysis has provided important, new information that can help Bacon scholars explain the anomalies long observed in Bacon's writings. Through an analysis of his autographic writings, we have disproved the possible claim that Bacon is unique, writing with a different wordprint at will. We are left with the following possibilities that scholars may wish to consider as explanations on a work-by-work basis:

(1) Some materials may have been written entirely by someone besides Bacon. This would seem to be the case, for example, with the frequently doubted Notes on the Present State of Christendom.

(2) Some materials may have been written with the extensive use of assistants. As reported above, Aubrey presents a convincing portrait of Bacon as the savant who customarily dictated his thoughts to his secretaries and otherwise used their assistance in the writing process. The widely divergent results of wordprinting analysis applied to his works suggest that these secretaries were likely formulating many phrases, sentences, and paragraphs to convey what they understood Bacon to intend to say. Word-for-word dictation would never produce this range of variation in the texts.

(3) In some writings, Bacon may have drawn so heavily on source materials that the composite measurable wordprint is a confusion of Bacon's (or some secretary's assigned to the task) with that of the underlying sources. There is evidence for this particularly in the histories, which draw heavily on the works of other authors. ${ }^{13}$ We might expect that such projects would be the easiest to delegate to secretaries as they required little or no development of an original intellectual argument. And in particular, we note, Hobbes was shown in Table 3 above to be a possible author of each of the histories that were published in Bacon's name.

Regardless of which of these explanations scholars will find most appropriate for each of Bacon's works, the overall conclusion may portray Francis Bacon as a less original, independent, and prolific writer than he has usually been understood to be. And the importance of identifying and understanding both his writing assistants and his sources will be correspondingly increased. Future studies using 
recently developed statistical authorship analysis methods coupled with authorship indicators other than the sixty-five we considered here will be useful in validating and extending these results.

\section{Acknowledgements}

The authors thank particularly Clark Asay, Brooksany Barrows, and Matthew Grow for their superb assistance on this project.

\section{References}

Anonymous. (1620). Horae Subsecivae: Observations and Discourses. London: Edward Blount.

Adolph, R. (1968). The Rise of Modern Prose Style. Cambridge, MA: MIT Press.

Aubrey, J. and Dick, O. (eds), (1957). Aubrey's Brief Lives. Ann Arbor, MI: University of Michigan Press.

Aughterson, K. (1992). The waking vision: Reference in the New Atlantis. Renaissance Quarterly, 95(Spring): $119-39$.

Bacon, F. and Rawley, W. (eds), (1657). Resuscitatio. London: William Lee.

Bacon, F. and Kiernan, M. (eds), (1985). The Essayes or Counsels, Civill and Morall. Cambridge, MA: Harvard University Press.

Busch, W. (1895).Todd, A. M. (1895). England Under the Tudors: King Henry VIII. New York: Burt Franklin.

Cornwallis, W. and Allen, D. C. (eds), (1946). Essayes. Baltimore: John Hopkins Press.

Crowther, J. G. (1960). Francis Bacon: The First Statesman of Science. London: Cresset Press.

Du Maurier, D. (1975). Golden Lads: A Study of Anthony Bacon, Francis, and their Friends. London: Victor Gollancz, Ltd.

Elliott, W. E. and Valenza, R. J. (1996). And then there were none: Winnowing the Shakespeare claimants. Computers and the Humanities, 30(3): 191-245.

Epstein, J. (1977). Francis Bacon: A Political Biographer. Athens, $\mathrm{OH}$ : Ohio University Press.

Fortier, J. (1997). Hobbes and the 'Discourses of Laws': The perils of wordprint analysis. Review of Politics, 59(Fall): 861-87.
Greville, F. and Gouw, J. (eds), (1986). The Prose Works of Fulke Greville, Lord Brooke. Oxford: Clarendon Press.

Hesse, M. (1964). Francis Bacon. In O'Connor, D. J. (ed.), A Critical History of Western Philosophy. New York: The Free Press.

Hilton, John L. and Jenkins, K. W. (1987). On maximizing author identification by measuring 5000 word texts. Brigham Young University Department of Statistics Technical Report Series SD-093-R. Provo, UT: Brigham Young University.

Hilton, John L. (1993). Continuing development and testing of a nonparametric procedure for objective author identification on 5000 word texts. Brigham Young University Department of Statistics Technical Report Series SD-094-R. Provo, UT: Brigham Young University.

Hilton, John L., Reynolds, N. B., and Saxonhouse, A. W. (1997). Hobbes and 'A Discourse of Laws': Response to Fortier. Review of Politics, 59(Fall): 889-903.

Hobbes, T. and Molesworth, W. (eds), (1966). The English Works of Thomas Hobbes of Malmesbury, 11 vols. Germany: Scienta Verlag Aalen.

Hobbes, T. and Macpherson, C. B. (eds), (1968). Leviathan. Harmondsworth: Penguin Books.

Hobbes, T. and Schlatter, R. (eds), (1975). Thucydides. New Brunswick: Rutgers University Press.

Hobbes, T. and Malcolm, N. (eds), (1994). The Correspondence. Oxford: Oxford University Press.

Holmes, D. I. (1985). The analysis of literary style: A review. Journal of the Royal Statistical Society, Series A, 148(part 4): 328-41.

Holmes, D. I. and Forsyth, R. S. (1995). The federalist revisited: New directions in authorship attribution. Literary and Linguistic Computing, 10(2): 111-27.

Jardine, L. and Stewart, A. (1999). Hostage to Fortune: The Troubled Life of Francis Bacon. New York: Hill and Wong.

Joliffe, I. T. (1986). Principal Components Analysis. New York: Springer.

Juola, P. (2006). Authorship attribution. Foundations and Trends in Information Retrieval, 1(3): 233-334.

Kiernan, M. (1985). Sir Francis Bacon: The Essayes or Counsels, Civill and Morall. Cambridge, MA: Harvard University Press.

Koppel, M., Schler, J., and Argamon, S. (2009). Computational methods in authorship attribution. Journal of The American Society for Information Science And Technology, 60: 9-26. 
Leary, J. E. (1994). Francis Bacon and the Politics of Science. Ames, IO: Iowa State University Press.

Lehman, E. L. (1975). Nonparametrics: Statistical Methods Based on Ranks. San Fransisco: Holden Day.

Malcolm, N. (1984). De Dominis, 1560-1624: Venetian, Anglican, Ecumenist, and Relapsed Heretic. London: Strickland and Scott Academic Publications.

Malcolm, N. (1996). A Summary Biography of Hobbes. In Sorrell, T. (ed.), The Cambridge Companion to Hobbes. Cambridge: Cambridge University Press.

Martinich, A. P. (1999). Hobbes: A Biography. Cambridge: Cambridge University Press.

Marwil, J. (1976). The Trials of Counsel: Francis Bacon in 1621. Detroit, MI: Wayne State University Press.

Michell, J. (1996). Who Wrote Shakespeare?. London: Thames \& Hudson.

Morton, A. Q. (1978). Literary Detection: How to Prove Authorship and Fraud in Literature and Documents. New York: Charles Scribner's Sons.

Peltonen, M. (1992). Politics and science: Francis Bacon and the true greatness of states. The Historical Journal, 35(June): 284.

Peltonen, M. (ed.) (1996). The Cambridge Companion to Bacon. Cambridge: Cambridge University Press.

Peng, R. D. and Hengartner, N. W. (2002). Quantitative analysis of literary styles. The American Statistician, 56(August): 171-85.

Reynolds, N. B. and Hilton, J. L. (1993). Thomas Hobbes and the authorship of the Horae Subsecivae. History of Political Thought, 14(Fall): 361-80.

Reynolds, N. B. and Saxonhouse, A. W. (1995). In Reynolds, N. B. (ed.), Thomas Hobbes, Three Discourses: A Critical Modern Edition of Newly Identified Work of the Young Hobbes. Chicago: University of Chicago Press.

Rogow, A. A. (1986). Thomas Hobbes: Radical in the Service of Reaction. New York: W. W. Norton.

SAS institute. SAS Software 8.2 (2001). Cary, North Carolina: SAS Institute.

40 Smedley, W. (1912). The Mystery of Francis Bacon. London: Robert Banks \& Son.

Spedding, J., Ellis, R., and Heath, D. (1857-74). The Works of Francis Bacon, 14 vols. London: Longman \& Co.

45 Stamatatos, E. (2009). A survey of modern authorship attribution methods. Journal of the American Society for Information Science and Technology, 60: 538-56.
Tuvill, D. and Lievsay, J. L. (eds), (1971). Essays Politic and Moral, and Essays Moral and Theological. Charlottesville, VA: The University Press of Virginia.

Urbach, P. (1987). Francis Bacon's Philosophy of Science: An Account and a Reappraisal. La Salle, IL: Open Court.

White, H. (1968). Peace Among the Willows: The Political Philosophy of Francis Bacon. The Hague: Martinus Nijhoff.

Zittel, C., Engel, G., Nanni, R., and Karafyllis, Nicole C. (eds), (2008). Philosophies of Technology: Francis Bacon and his Contemporaries. Leiden: Brill.

\section{Notes}

1 These discourses were first published as part of the Horae Subsecivae: Observations and Discourses (Anonymous, 1620), and most recently with explanatory materials by Reynolds and Saxonhouse (1995). The complete report of the statistical study was published earlier by Reynolds and Hilton (1993).

2 Most famously, he has been vigorously proposed to be the author of Shakespeare's works by a long train of 'Baconians', as is documented and reviewed by John Michell (1996, pp. 113-60).

3 John Fortier (1997) used those results to ground his challenge to our conclusions about Hobbes. The present study completely resolves the questions in our first attempt to wordprint Bacon's writings as explained in detail in our reply, published with Fortier's piece.

4 The method is described in detail by Hilton and Jenkins (1987). Applications of the method along with shorter descriptions can be found in Reynolds and Hilton (1993) and Elliott and Valenza (1996).

5 For a discussion of the use of principal components analysis in wordprinting, see Peng and Hengartner (2002) and Holmes and Forsyth (1995).

6 See the complete list in Reynolds and Saxonhouse (1995), 166-69, as extracted from Morton (1978).

7 Yet if the translation into English had been done in a completely free, nonliteral manner as in an English paraphrase, so as to remove all of the original Latin, non-English sentence structure, then a valid wordprint comparison may be measured for the translator but not for the original foreign language writing author. However, if both compared texts come from academic 'literal' translations from the same original, nonEnglish language, then a wordprint measurement that could identify the original author is sometimes obtainable. 
8 Francis Bacon, The Works of Francis Bacon and The Letters and the Life of Francis Bacon (Spedding et al., 1857-74) were our sources for nearly all text blocks (hereafter Works). The exceptions were the 1625 edition of the essays, which came from Francis Bacon, The Essayes or Counsels, Civill and Morall, and one text block from Francis Bacon's Resuscitatio (Bacon and Rawley, 1657).

9 The editions used for these text blocks are as follows: The English Works of Thomas Hobbes of Malmesbury (Hobbes and Molesworth, 1966); Leviathan (Hobbes and Macpherson, 1968); Thucydides (Hobbes and Schlatter, 1975); and Reynolds and Saxonhouse, 1995.

10 The editions used for these blocks are as follows: Essays Politic and Moral, and Essays Moral and Theological (Tuvill and Lievsay, 1971); The Prose Works of Fulke Greville (Greville and Gouw, 1986); Essayes (Cornwallis and Allen, 1946).

11 The expected result from using one co-authored text against a single-authored work in our tests is an increase in the variance along with an unpredictable increase or decrease in the measured distance score, depending on how dissimilar the co-author's writing habits are to those of the principal author's. Of course, with an increase in variance, the distance score between the pair of tests would decrease, and so the lower end of the distance-score distribution where the within-author distributions are measured will become increasingly ambiguous.

12 Aubrey's Brief Lives, 9. Arnold A. Rogow (1986), explains that this essay is mistitled by Aubrey and is in reality Of the True Greatnesse of Kingdomes and Estates, which an authority on Bacon has described as 'one of the best translated of all' of Bacon's essays.

13 Wilhelm Busch (1895) showed the scholarly world that Bacon's History of Henry VII was not an original work, but was rather derived completely from Edward Hall, who in turn had drawn heavily on Polydore Vergil and to a lesser extent on Bernard Andre. 